\title{
The Efficacy of a Long-Acting Injectable Selenium Preparation Administered to Pregnant Ewes and Lambs
}

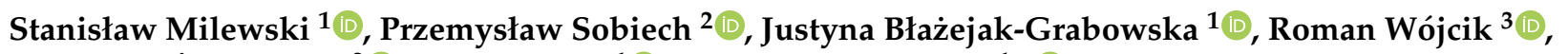 \\ Katarzyna Żarczyńska ${ }^{2}$ (D), Jan Miciński ${ }^{1}$ (D) and Katarzyna Ząbek ${ }^{1, *(D)}$ \\ 1 Department of Sheep and Goat Breeding, Faculty of Animal Bioengineering, University of Warmia and \\ Mazury in Olsztyn, Oczapowskiego 5, 10-719 Olsztyn, Poland; stanmil@uwm.edu.pl (S.M.); \\ justyna.blazejak@uwm.edu.pl (J.B.-G.); micinsk@uwm.edu.pl (J.M.) \\ 2 Department of Internal Diseases, Faculty of Veterinary Medicine, University of Warmia and Mazury \\ in Olsztyn, Oczapowskiego 14, 10-719 Olsztyn, Poland; psobiech@uwm.edu.pl (P.S.); \\ katarzyna.zarczynska@uwm.edu.pl (K.Ż.) \\ 3 Department of Microbiology and Clinical Immunology, Faculty of Veterinary Medicine, University of Warmia \\ and Mazury in Olsztyn, Oczapowskiego 13, 10-719 Olsztyn, Poland; brandy@uwm.edu.pl \\ * Correspondence: katarzyna.zabek@uwm.edu.pl
}

check for updates

Citation: Milewski, S.; Sobiech, P.; Błażejak-Grabowska, J.; Wójcik, R.; Żarczyńska, K.; Miciński, J.; Ząbek, K. The Efficacy of a Long-Acting Injectable Selenium Preparation Administered to Pregnant Ewes and Lambs. Animals 2021, 11, 1076. https://doi.org/10.3390/ani11041076

Academic Editor:

María-Teresa Paramio

Received: 23 March 2021

Accepted: 8 April 2021

Published: 9 April 2021

Publisher's Note: MDPI stays neutral with regard to jurisdictional claims in published maps and institutional affiliations.

Copyright: (C) 2021 by the authors. Licensee MDPI, Basel, Switzerland. This article is an open access article distributed under the terms and conditions of the Creative Commons Attribution (CC BY) license (https:/ / creativecommons.org/licenses/by/ $4.0 /)$.
Simple Summary: Lack of selenium (Se) is a global problem that leads to increased exposure of animals to various diseases, as well as a reduction in productive and reproductive performance. Mineral supplementation can improve the immune system and could therefore be of assistance for lambs. We studied the effects of injectable supplementation with selenium. Supplementation of the Se lead to improved immune status, blood parameters, body weights, and average daily gain of lambs.

Abstract: The aim of this study was to evaluate the effects of a long-acting selenium (Se) preparation administered to sheep. The experiment was conducted on 30 dams and 36 lambs divided into three equal groups of $10 \mathrm{dams}$ and 12 lambs each: Control $-\mathrm{C}$, and two experimental groups-E (Se administered to pregnant ewes) and EI (Se administered directly to lambs after the colostral period). The Se preparation (Barium Selenate Injection, BVP Animal Care, $50 \mathrm{mg} / \mathrm{mL}$ ) was administered by injection at $1 \mathrm{~mL} / 50 \mathrm{~kg}(1 \mathrm{mg} \mathrm{Se} / \mathrm{kg})$ body weight $(\mathrm{BW})$ to group E ewes in the third month of pregnancy (between 70 and 90 days) and to group EI lambs between 4 and 7 days of age. The following parameters were determined: Se concentration in the blood of ewes, milk yield, milk composition, Se concentration in milk; hematological, biochemical, and immunological parameters and Se concentration in the blood of lambs; growth rate and in vivo measurements of lean meat and fat content in lambs. Barium selenate significantly improved the Se status of dams and lambs, regardless of whether it was administered to pregnant ewes or directly to lambs in the first week of their life. The milk of ewes receiving the Se preparation was characterized by higher concentrations of fat and dry matter. The Se preparation induced significant changes in immunological parameters, thus enhancing defense mechanisms in lambs. The Se preparation exerted more stimulatory effects on humoral and cellular immune responses when administered directly to lambs after the colostral period (group EI) than to pregnant ewes (group E). The results of this study indicate that the longacting Se preparation delivers benefits to sheep by boosting their immunity and, therefore, improving performance.

Keywords: barium selenate; sheep; immunity; performance

\section{Introduction}

Selenium (Se) is a trace element that is required for healthy body functioning, and Se deficiency can compromise the health status of animals and, consequently, decrease their components and biological availability $[1,2]$. Se is common on the earth's surface, but its 
concentration and distribution are not uniform. There are areas with soils either poor or rich in this element. Most soils in the world have low content of this element. Se deficiency is more of a problem geographically than is selenium toxicity. The selenium content of forages varies with the type of feed, the type of soil, and the region [2]. Se levels are low in soil and in green forage that is consumed by sheep in the basal diet. In ruminants, this micromineral is relatively poorly absorbed from feed because rumen microbes partially reduce much of dietary inorganic selenium to unabsorbable elemental or inorganic selenide forms [3].

The absorption of selenium from the given food differs significantly in mono and polygastric animals. In the former it reaches $80 \%$, while in ruminants it does not exceed $51 \%$ [4]. Calves, lambs, and goatlings use significantly more of this element than adults-it is related to the still undeveloped rumen function. The main rumen microorganisms that can incorporate selenium into their structures are bacteria belonging to the species: $\mathrm{Bu}$ tyvibrio fibrisolvens, Prevotella ruminicola, Selenomonas ruminantium, as well as Streptococus sp. and Lactobacillus sp. [5]. Pure cultures of Selenomonas ruminantium and Butyvibrio fibrisolvens incorporate selenium into selenoamino acids, while Prevotella ruminicola metabolizes selenium compounds into an elemental form-inaccessible to a higher organisms [6]. Studies performed on sheep have shown [7] that lower selenium absorption in animals fed green fodder is associated with the presence of the latter microorganism, while in the high-energy diet (concentrated feed) in the rumen, Selenomonas ruminantium bacteria predominate, increasing the bioavailability of the collected element.

Therefore, livestock diets have to be supplemented with Se. In sheep, Se is generally administered via the parenteral route. The most commonly used is sodium selenate and vitamin E preparations with a period of action not exceeding a few weeks, and the treatment has to be repeated. Long-acting preparations that release Se over a period of several months appear to be a more effective solution. Barium selenate is one of such formulations. However, the effectiveness of barium selenate supplements remains insufficiently investigated. In a study by Annett et al. [8], barium selenate significantly improved the Se status of lambs. Ceballos et al. [9] demonstrated that barium selenate administered one month before calving effectively prevented mastitis in dairy cows.

The aim of this study was to determine the efficacy of a single injectable dose of barium selenate administered to pregnant ewes or to lambs in the first week of their life. The research hypothesis states that barium selenate increases Se concentrations in the blood and milk of ewes, increases milk yield, improves milk composition, enhances the health status of lambs, and improves meat performance.

\section{Materials \& Methods}

The experiment was approved by the Local Ethics Committee for Animal Experimentation of the University of Warmia and Mazury in Olsztyn (decision No. 68/2014). The study was conducted on a breeding herd of Pomeranian sheep. The study was conducted in Baldram (Poland), located at $53^{\circ} 45^{\prime}$ North latitude, $18^{\circ} 56^{\prime}$ East longitude. Thirty ewes aged 3-4 years were divided into two analogue groups: C-control (15 ewes) and Eexperimental (15 ewes), based on age and body weights (BW). The groups were established at the end of the third month of pregnancy (between 70 and 90 days-this moment is understood as day 0), as confirmed by an ultrasound examination performed with the Mindray DP50 scanner with an abdominal probe in the 3.5-5 MHz frequency range. Experimental group ewes were subcutaneously (skin fold neck) injected with a long-acting Se preparation (Barium Selenate Injection, BVP Animal Care, Ireland, $50 \mathrm{mg}$ of Se in $1 \mathrm{~mL}$ ) at $1 \mathrm{~mL} / 50 \mathrm{~kg}$ body weight, which gives dosage $1 \mathrm{mg} \mathrm{Se} / 1 \mathrm{~kg} B W$ of ewes. Based on birth result, 10 mothers and their 12 lambs (including 8 singletons and 4 twins, with equal proportions of each sex) were selected for further research from each of these groups (C and E). During lambing, a second experimental group (EI) composed of 10 dams and 12 lambs from other animals kept in the herd was created. Group EI animals were identical to the remaining groups in terms of the BW and age of dams, the BW of lambs, the number 
of singletons and twins, and the sex ratio. Third group EI (12 lambs) were injected with barium selenate at a dose of $1 \mathrm{~mL} / 50 \mathrm{~kg}$ BW between 4 and 7 days of age (day 0 ), which gives dosage $1 \mathrm{mg} \mathrm{Se} / 1 \mathrm{~kg}$ BW of lambs. The lambs were kept with their dams until 100 days of age. Dam diets had the following composition (kg/animal/day): Meadow hay -1.0 ; barley straw -0.5 ; dried beet pulp -0.5 ; CJ concentrate -0.3 during pregnancy and 0.6 during lactation. Beginning at 11 days of age, suckling lambs had ad libitum access to meadow hay and the $\mathrm{CJ}$ concentrate. The chemical composition of the diets is presented in Table 1. The CJ ${ }^{\circledR}$ concentrate had the following composition: Ground barley $(40 \%)$, ground wheat $(37.5 \%)$, ground maize $(10 \%)$, soybean meal $(10 \%)$, mineral premix $(2 \%)$, fodder chalk $(0.2 \%)$, dicalcium phosphate $(0.2 \%)$, and salt fodder $(0.1 \%)$. Animals all groups had unrestricted access to Multi-Lisal salt licks, which contains: Nacl-94\%, waterinsoluble substances—max. $\%$, Mg $2000 \mathrm{mg} / \mathrm{kg}, \mathrm{Co}-18 \mathrm{mg} / \mathrm{kg}, \mathrm{Zn}$ (zinc)— $810 \mathrm{mg} / \mathrm{kg}$, $\mathrm{Mn}-830 \mathrm{mg} / \mathrm{kg}$, I (Iodine)—100 mg/ $\mathrm{kg}$, Se (selenium) - $10 \mathrm{mg} / \mathrm{kg}$. Due to the fact that in the whole herd the feeding program included constant access to licks for all animals, therefore, the supply of selenium from the licks was assumed in the same dosage for both the control and experimental groups.

Table 1. Chemical composition of dams diets (\% of fresh matter).

\begin{tabular}{|c|c|c|c|c|}
\hline Specification & $\mathrm{CJ}^{\circledR}$ Concentrate & Cereal Straw & Meadow Hay & Dried Beet Pulp \\
\hline \multicolumn{5}{|c|}{ Chemical Composition } \\
\hline Dry matter (\%) & 88.99 & 91.01 & 84.98 & 93.11 \\
\hline Crude ash (\%) & 5.59 & 7.01 & 9.79 & 4.81 \\
\hline Crude protein $(\%)$ & 19.32 & 4.22 & 7.25 & 5.05 \\
\hline Crude fat $(\%)$ & 3.42 & 1.54 & 0.82 & 0.82 \\
\hline Crude fiber $(\%)$ & 6.92 & 43.2 & 28.62 & 14.03 \\
\hline Selenium (mg/kg) & 0.15 & 0.025 & 0.023 & 0.047 \\
\hline Gross energy MJ kg-1 & 16.14 & 16.89 & 16.22 & 15.88 \\
\hline
\end{tabular}

Dried beet pulp was incorporated into lamb diets on day 31, and the composition of lamb diets was normalized. The quantity of each dietary ingredient in the daily ration of lambs was increased by $0.05 \mathrm{~kg}$ every 10 days, beginning with $0.15 \mathrm{~kg}$ of hay, $0.15 \mathrm{~kg}$ of the CJ concentrate, and $0.05 \mathrm{~kg}$ of dried beet pulp between days 31 and 40 of age.

Blood samples were collected from the jugular vein. Hematological parameters: Red blood cell counts (RBC), white blood cell counts (WBC), hemoglobin (HBG), hematocrit (HCT), mean corpuscular volume (MCV), mean corpuscular hemoglobin $(\mathrm{MCH})$, mean corpuscular hemoglobin concentration (MCHC), platelet counts (PLT), and mean platelet volume (MPV) were determined in full blood, using the Vet Animal Blood Counter 18 (Horiba ABX SAS). Blood samples for biochemical tests were collected into polyethylene tubes containing clot activating beads. Samples for biochemical analyses were centrifuged immediately after collection (10 min, $3000 \mathrm{rpm})$. The obtained serum was stored in individual test tubes at $-18{ }^{\circ} \mathrm{C}$ until further analysis. Biochemical analyses of the serum were performed within $4 \mathrm{~h}$ after collection. The following biochemical parameters were determined: Glucose (GLU) and total protein (TP) levels; the activity of aspartate transaminase (AST), alkaline phosphatase (ALP), lactate dehydrogenase (LDH), gamma-glutamyl transpeptidase (GGT); and the concentrations of cholesterol (Chol), triglycerides (TG), and Se. The following analytical methods were used: Glucose concentration was determined with the use of glucose oxidase [10], total protein was determined by the biuret method [11], cholesterol - by the colorimetric method with cholesterol esterase and cholesterol oxidase [12], triglycerides-by the enzymatic method with glycerophosphate oxidase [13], AST activity — by the kinetic method [14], LDH activity - by the kinetic method with Cormay reagents [15], GGT activity - by the kinetic method with l-glutamyl-3-carboxy4-nitroanilide [16], ALP activity—by the kinetic method [17]. All determinations were performed using an ACCENT 200 automated chemistry analyzer (Cormay) and commercial 
Cormay diagnostic kits. Serum Se levels were determined in triplicate by graphite furnace atomic absorption spectrometry in LABOKLIN Laboratory for Clinical Diagnostics $\mathrm{GmbH}$ \& Co. KG (Bad Kissingen, Germany).

The following humoral immunity parameters were determined: Lysozyme and ceruloplasmin activity and gamma globulin concentrations. Cellular immunity mechanisms were analyzed based on specific and non-specific immunity parameters: Respiratory burst activity (RBA) and potential killing activity (PKA) of phagocytes, and the proliferative response of mitogen-stimulated T-cells and B-cells. Lysozyme activity in the blood plasma was determined by the method described by Siwicki and Anderson [18], and ceruloplasmin activity — by the method proposed by Siwicki and Studnicka [19]. The serum concentrations of gamma globulins were determined by the micromethod proposed by Lowry and modified by Siwicki and Anderson [18]. Respiratory burst activity, i.e., the metabolic activity of phagocytes stimulated with phorbol myristate acetate (PMA), was measured by spectrophotometry (OD $620 \mathrm{~nm}$ ). The PKA of polymorphonuclear and mononuclear phagocytes was determined by spectrophotometry (OD $620 \mathrm{~nm}$ ). The proliferative response of T-cells stimulated with concavalin A (ConA) and B-cells stimulated with lipopolysaccharide (LPS) was determined by MTT-based spectrophotometry.

Selenium concentration in milk and diets were determined by inductively coupled plasma mass spectrometry (ICP-MS) in the J.S. Hamilton Poland laboratory.

Daily milk production was determined based on the results of the morning milking test performed $12 \mathrm{~h}$ after the previous milking. The animals were administered $2.5 \mathrm{U}$ of oxytocin (Oxytocinum Biowet, Puławy) approximately $2 \mathrm{~min}$ before milking to stimulate the contraction of myoepithelial cells surrounding the mammary alveoli, and lactiferous ducts. The right half of the udder was milked manually, whereas the other half was simultaneously sucked by a lamb. The quantity of collected milk was multiplied by 4 to obtain the daily milk yield according to the method described by Zabek et al. 2014 [20]. Milk was analyzed to determine the percentage content of dry matter, fat, protein and lactose, and somatic cell counts (SCC) per ml. The analyses were performed in the Combi Foss 6000 system.

The height, width, and cross-sectional area of the musculus longissimus dorsi (m.l.d.) and fat thickness over the loin eye were determined with the Mindray DP50 ultrasound scanner with a $5 \mathrm{MHz}$ linear probe. The measurements were conducted in vivo at the level of the last thoracic vertebra [21].

The results were processed statistically, and the significance of differences between groups was verified by Duncan's test. Blood indices and Se concentration were analyzed in a static and dynamic system relevant to day 0. Data were processed in the Statistica 13.1 program. The experiments were carried out in accordance with the established standards for animal experimentation.

Differences across treatment groups were estimated with the use of the below formula:

$$
Y_{i j}=\mu+\alpha_{i}+e_{i j}
$$

where: $Y_{i j}$-dependent variable; $\mu$-overall mean; $\alpha_{i}$-fixed effect of treatment; $e_{i j}$ random residual error.

Blood indices and serum Se concentration were evaluated by repeated measures with the following formula:

$$
Y_{i j k}=\mu+\alpha+\beta_{j}+T_{i} * t_{j}+e_{i j}
$$

where: $Y_{i j k}$-dependent variable; $\mu$-overall mean; $\alpha_{i}$-fixed effect of treatment; $\beta_{j}$-effect of sampling date (days $0,28,70$ or 100); $T_{i}{ }^{*} t_{j}$-fixed effect of treatment $x$ time interaction, $e_{i j}$-random residual error.

\section{Results}

The Se preparation increased serum Se levels in dams (group E) (Figure 1). Dams had a similar concentration of Se in the blood on day 0 -in the third month of pregnancy. 
Serum Se concentration was significantly higher in the experimental group than in the control group on successive days of lactation. This parameter was higher by $16.89 \mu \mathrm{g} / \mathrm{L}$ $(p \leq 0.01)$ on day 28 , and 12.31 and $7.41 \mu \mathrm{g} / \mathrm{L}(p \leq 0.01)$ on days 70 and 100 , respectively. In these group of dams, serum Se concentration was significantly higher on every successive sampling date relative to day $0(p \leq 0.01)$. This parameter remained at a stable level in the control group.

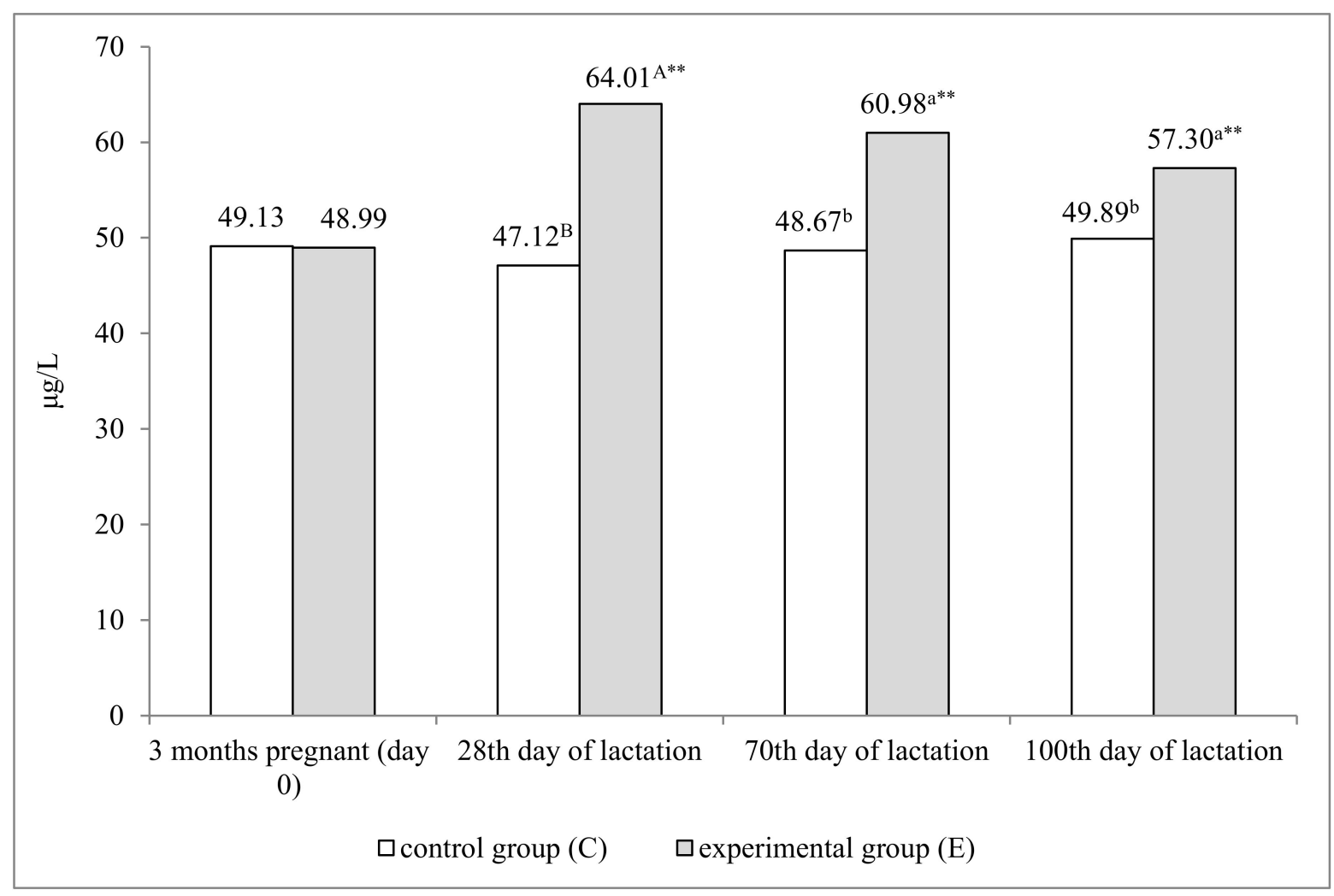

Figure 1. Serum Se concentration in dams from control group $C$ and experimental group $E(\mu g / L) a, b-p \leq 0.05 ; A$, $\mathrm{B}-p \leq 0.01 .{ }^{* *} p \leq 0.01$ - significant difference relative to day 0 ( 3 months pregnant).

Milk yield, milk quality, and Se concentration in milk are presented in Table 2. The administered preparation did not affect average daily milk yields. An analysis of the proximate chemical composition of milk revealed that on lactation day 70 , fat content and, consequently, dry matter concentration were highest in group E ewes that received the Se preparation during pregnancy. The differences in both parameters were significant $(p \leq 0.05)$ relative to group C. The tested preparation had no significant effect on SCC in milk. There was no statistically significant difference in Se concentration between the milk of group E dams and milk of dams from remaining group.

The hematological parameters determined in the blood of lambs are presented in Table 3. A morphological analysis of lamb peripheral blood did not reveal significant differences in leukocyte or erythrocyte counts across groups during the entire experiment. A similar trend was noted in hemoglobin concentration. The analyzed parameters were within the reference ranges for the species. The remaining hematological parameters (MCV, $\mathrm{HCT}, \mathrm{MCHC}, \mathrm{PLT}$, and MPV) were also similar and within the norm in all lamb groups. 
Table 2. Daily milk yield, milk composition, somatic cell counts, and selenium concentration in milk.

\begin{tabular}{|c|c|c|c|c|c|c|c|c|c|c|}
\hline \multirow[b]{2}{*}{ Parameter } & \multicolumn{3}{|c|}{ Lactation Day 28} & \multicolumn{3}{|c|}{ Lactation Day 70} & \multirow[b]{2}{*}{ SEM } & \multicolumn{3}{|c|}{$p$-Value } \\
\hline & $C(n=10)$ & $E(n=10)$ & $\mathrm{EI}(\mathrm{n}=10)$ & $C(n=10)$ & $E(n=10)$ & $\mathrm{EI}(\mathrm{n}=10)$ & & Group & Date & $\begin{array}{l}\text { Group } \\
\times \text { Date }\end{array}$ \\
\hline Milk yield (mL/d) & 1528.4 & 1567.8 & 1537.3 & 1056.2 & 1083.6 & 1047.7 & 32.97 & 0.053 & 0.095 & 0.748 \\
\hline Dry matter (\%) & 3.82 & 16.36 & 15.66 & $15.82^{b}$ & $16.72^{\mathrm{a}}$ & 16.12 & 1.096 & 0.021 & 0.110 & 0.994 \\
\hline Fat $(\%)$ & 5.05 & 5.67 & 5.27 & $5.29^{b}$ & $6.02^{\mathrm{a}}$ & 5.64 & 0.620 & 0.056 & 0.151 & 0.969 \\
\hline Protein (\%) & 4.72 & 5.12 & 4.80 & 4.95 & 5.28 & 4.91 & 0.174 & 0.075 & 0.321 & 0.750 \\
\hline Lactose (\%) & 5.23 & 5.26 & 5.29 & 5.28 & 5.35 & 5.26 & 0.061 & 0.835 & 0.582 & 0.743 \\
\hline $\operatorname{SCC}\left(10^{3} / \mathrm{mL}\right)$ & 272.00 & 201.50 & 226.00 & 140.10 & 134.50 & 150.40 & 12.97 & 0.363 & 0.111 & 0.584 \\
\hline Selenium ( $\mu \mathrm{g} / \mathrm{L})$ & 0.134 & 0.164 & 0.121 & 0.245 & 0.325 & 0.241 & 0.001 & 0.542 & 0.058 & 0.366 \\
\hline
\end{tabular}

$\mathrm{a}, \mathrm{b}-p \leq 0.05$; SCC—somatic cell count; SEM—standard error of measurement.

Table 3. Hematological parameters in lambs.

\begin{tabular}{|c|c|c|c|c|c|c|c|c|c|c|c|c|c|c|c|c|}
\hline \multirow[b]{2}{*}{ Parameter } & \multicolumn{3}{|c|}{ 4-7 Days of Age (Day 0) } & \multicolumn{3}{|c|}{28 Day of Age } & \multicolumn{3}{|c|}{70 Day of Age } & \multicolumn{3}{|c|}{100 Day of Age } & \multirow[t]{2}{*}{ SEM } & \multicolumn{3}{|c|}{$p$-Value } \\
\hline & $\begin{array}{l}\text { C (n } \\
=12)\end{array}$ & $\begin{array}{c}E(n \\
=12)\end{array}$ & $\begin{array}{l}\text { EI (n } \\
=12)\end{array}$ & $\begin{array}{l}C(n \\
=12)\end{array}$ & $\begin{array}{c}E(n \\
=12)\end{array}$ & $\begin{array}{l}\text { EI (n } \\
=12)\end{array}$ & $\begin{array}{l}C \text { C (n } \\
=12)\end{array}$ & $\begin{array}{c}\text { E (n } \\
=12)\end{array}$ & $\begin{array}{l}\text { EI (n } \\
=12)\end{array}$ & $\begin{array}{l}C(n \\
=12)\end{array}$ & $\begin{array}{c}E(n \\
=12)\end{array}$ & $\begin{array}{l}\text { EI (n } \\
=12)\end{array}$ & & Group & Date & $\begin{array}{l}\text { Group } \\
\times \text { Date }\end{array}$ \\
\hline $\mathrm{WBC}\left(10^{9} / \mathrm{L}\right)$ & 8.38 & 8.42 & 8.41 & 8.43 & 8.46 & 8.83 & 8.44 & 8.52 & 9.17 & 8.41 & 8.59 & 9.79 & 4.06 & 0.132 & 0.095 & 0.167 \\
\hline $\operatorname{RBC}\left(10^{12} / \mathrm{L}\right)$ & 10.28 & 10.33 & 10.32 & 10.38 & 10.45 & 10.59 & 10.39 & 10.42 & 10.92 & 10.37 & 10.48 & 11.10 & 0.958 & 0.280 & 0.169 & 0.106 \\
\hline $\mathrm{HGB}(\mathrm{g} / \mathrm{dL})$ & 11.28 & 11.33 & 11.35 & 11.33 & 11.51 & 11.63 & 11.29 & 11.67 & 12.04 & 11.28 & 11.70 & 12.01 & 0.622 & 0.101 & 0.194 & 0.652 \\
\hline HCT $(\%)$ & 34.83 & 34.87 & 34.79 & 35.12 & 35.16 & 35.11 & 35.02 & 35.36 & 35.28 & 35.25 & 35.62 & 35.53 & 4.83 & 0.521 & 0.156 & 0.247 \\
\hline MCV (fl) & 34.97 & 34.88 & 34.92 & 35.83 & 34.50 & 33.84 & 35.92 & 34.41 & 33.58 & 34.91 & 34.02 & 32.36 & 4.98 & 0.332 & 0.920 & 0.496 \\
\hline $\mathrm{MCH}(\mathrm{pg})$ & 10.28 & 10.27 & 10.29 & 10.33 & 10.29 & 10.29 & 10.32 & 10.30 & 10.29 & 10.33 & 10.29 & 10.27 & 0.598 & 0.277 & 0.068 & 0.428 \\
\hline $\mathrm{MCHC}(\mathrm{g} / \mathrm{dL})$ & 31.98 & 32.51 & 32.84 & 32.51 & 32.60 & 33.06 & 32.94 & 33.21 & 33.18 & 33.12 & 33.44 & 33.51 & 1.64 & 0.077 & 0.376 & 0.204 \\
\hline PLT $\left(10^{9} / \mathrm{L}\right)$ & 653.71 & 633.12 & 663.78 & 663.12 & 648.45 & 689.82 & 689.33 & 673.19 & 708.22 & 673.24 & 685.91 & 699.14 & 24.70 & 0.780 & 0.158 & 0.093 \\
\hline MPV (fl) & 8.27 & 8.46 & 8.12 & 9.29 & 9.45 & 9.02 & 9.34 & 9.51 & 9.38 & 9.02 & 9.41 & 9.44 & 0.797 & 0.135 & 0.112 & 0.289 \\
\hline
\end{tabular}

SEM—standard error of measurement, WBC—white blood cell counts, RBC—red blood cell counts, HBG—hemoglobin, HCT—hematocrit, $\mathrm{MCV}$-mean corpuscular volume, $\mathrm{MCH}$ - mean corpuscular hemoglobin, $\mathrm{MCHC}$ - mean corpuscular hemoglobin concentration, PLTplatelet count, MPV_-mean platelet volume.

The biochemical parameters determined in the blood of lambs are presented in Table 4. Serum glucose levels in groups $\mathrm{E}$ and EI were higher than in the control group. This trend was maintained during the entire experiment, but significant differences were not determined in the static or the dynamic approach. Total protein concentration in control group lambs ranged from $47.12 \mathrm{~g} / \mathrm{L}$ to $48.91 \mathrm{~g} / \mathrm{L}$ during the experiment. Groups E and EI differed in total protein concentration on successive sampling dates. On day 0 , total protein was higher in group E (57.34 g/L) than in group C (48.22 g/L) and group EI $(48.21 \mathrm{~g} / \mathrm{L})$. On the remaining sampling dates, total protein concentration was highest in group EI. However, the observed differences were not statistically significant. In all groups, AST activity fluctuated during the study, but the noted differences were not significant. The activities of ALP, LDH, and GGT were similar in all groups.

Table 4. Biochemical parameters in lambs.

\begin{tabular}{|c|c|c|c|c|c|c|c|c|c|c|c|c|c|c|c|c|}
\hline \multirow[b]{2}{*}{ Parameter } & \multicolumn{3}{|c|}{ 4-7 Days of Age (Day 0) } & \multicolumn{3}{|c|}{28 Day of Age } & \multicolumn{3}{|c|}{70 Day Of Age } & \multicolumn{3}{|c|}{100 Day of Age } & \multirow[b]{2}{*}{ SEM } & \multicolumn{3}{|c|}{$p$-Value } \\
\hline & $\begin{array}{l}C(n \\
=12)\end{array}$ & $\begin{array}{c}E(n \\
=12)\end{array}$ & $\begin{array}{l}\text { EI (n } \\
=12)\end{array}$ & $\begin{array}{l}C(n \\
=12)\end{array}$ & $\begin{array}{c}E(n \\
=12)\end{array}$ & $\begin{array}{l}\text { EI (n } \\
=12)\end{array}$ & $\begin{array}{l}C(n \\
=12)\end{array}$ & $\begin{array}{c}E(n \\
=12)\end{array}$ & $\begin{array}{l}\text { EI (n } \\
=12)\end{array}$ & $\begin{array}{l}C(n \\
=12)\end{array}$ & $\begin{array}{c}E(n \\
=12)\end{array}$ & $\begin{array}{l}\text { EI (n } \\
=12)\end{array}$ & & Group & Date & $\underset{\text { Date }}{\text { Group }} \times$ \\
\hline $\begin{array}{c}\text { GLU } \\
(\mathrm{mmol} / \mathrm{L})\end{array}$ & 4.75 & 4.80 & 4.79 & 4.76 & 4.82 & 4.83 & 4.72 & 4.81 & 4.84 & 4.74 & 4.83 & 4.89 & 0.170 & 0.090 & 0.900 & 0.119 \\
\hline $\mathrm{TP}(\mathrm{g} / \mathrm{L})$ & 48.22 & 57.34 & 48.21 & $47.12^{\text {B }}$ & $60.45^{\mathrm{B}}$ & $69.87^{\mathrm{A} * *}$ & $48.91^{\text {В }}$ & $55.33^{\text {B }}$ & $67.37^{\mathrm{A}}$ & $48.03^{\text {В }}$ & $47.19^{\text {В }}$ & $68.45^{\mathrm{A} *}$ & 29.6 & 0.002 & 0.002 & 0.694 \\
\hline AST (U/L) & 75.04 & 64.16 & 74.08 & 82.96 & 64.22 & 64.18 & 87.28 & 64.21 & 64.02 & 90.59 & 64.34 & 64.12 & 36 & 0.057 & 0.1 & 0.114 \\
\hline $\operatorname{ALP}(\mathrm{U} / \mathrm{L})$ & 325.64 & 338.92 & 329.55 & 350.87 & 365.39 & 352.64 & 399.25 & 372.44 & 392.39 & 380.72 & 398.58 & 402.56 & 115.86 & 0.657 & 0.218 & 0.157 \\
\hline $\mathrm{LDH}(\mathrm{U} / \mathrm{L})$ & 1040.00 & 938.54 & 1002.71 & 1187.37 & 962.56 & 972.59 & 1222.45 & 973.92 & 994.13 & 1253.37 & 983.15 & 997.98 & 229.19 & 0.714 & 0.140 & 0.615 \\
\hline GGT (U/L) & 56.82 & 57.34 & 57.92 & 57.88 & 57.45 & 58.02 & 59.32 & 60.02 & 59.89 & 59.98 & 60.12 & 60.08 & 11.88 & 0.716 & 0.178 & 0.229 \\
\hline $\begin{array}{c}\text { Chol } \\
(\mathrm{mmol} / \mathrm{L})\end{array}$ & 2.02 & 2.15 & 2.14 & 2.09 & 2.20 & 2.22 & 2.07 & 2.25 & 2.28 & 2.09 & 2.23 & 2.28 & 0.679 & 0.323 & 0.145 & 0.515 \\
\hline $\begin{array}{c}\mathrm{TG} \\
(\mathrm{mmol} / \mathrm{L})\end{array}$ & 0.42 & 0.36 & 0.38 & 0.45 & 0.37 & 0.37 & 0.47 & 0.37 & 0.36 & $0.52^{\mathrm{a}}$ & $0.39^{b}$ & $0.38^{\mathrm{b}}$ & 0.030 & 0.017 & 0.169 & 0.761 \\
\hline
\end{tabular}

$\mathrm{a}, \mathrm{b}-p \leq 0.05 ; \mathrm{A}, \mathrm{B}-p \leq 0.01 .{ }^{*} p \leq 0.05 ;{ }^{* *} p \leq 0.01-$ significant difference relative to day 0 . SEM-standard error of measurement. GLU—glucose, TP — total protein, AST—the activity of aspartate transaminase, ALP — the activity of alkaline phosphatase, LDH—lactate dehydrogenase, GGT_gamma-glutamyl transpeptidase, Chol—the concentrations of cholesterol, TG-triglycerides. 
Triglyceride levels were similar in all lambs on the first three sampling dates, but they were significantly lower in groups E and EI on day $100(p \leq 0.05)$. In contrast, cholesterol concentration remained similar in all lambs during the experiment.

An analysis of humoral defense mechanisms in lambs (Table 5) revealed that the Se preparation significantly increased the values of all evaluated parameters. Lysozyme activity was highest in lambs that were directly administered the Se preparation (group EI), and significant differences relative to the remaining groups were observed on days 28, 70, and 100. In group EI lambs, lysozyme activity increased significantly $(p \leq 0.01)$ on days 70 and 100 , relative to day 0 . In group $E$ lambs, lysozyme activity was higher than in group C on days 70 and 100, but the noted differences were not significant. Lysozyme activity in group E lambs was higher on day 100 relative to day 0. Similar trends were observed in ceruloplasmin activity and gamma globulin levels. These parameters were significantly higher in group EI than in the remaining groups. The observed differences were significant at $p \leq 0.05$ on day 28 and at $p \leq 0.01$ on days 70 and 100. A dynamic analysis revealed that both parameters increased significantly with lambs' age, and that relative to day 0 , the observed increase was significant at $p \leq 0.05$ on day 28 and at $p \leq 0.01$ on the remaining sampling dates.

Table 5. Immunological parameters in lambs.

\begin{tabular}{|c|c|c|c|c|c|c|c|c|c|c|c|c|c|c|c|c|}
\hline \multirow[b]{2}{*}{ Parameter } & \multicolumn{3}{|c|}{ 4-7 Days of Age (Day 0) } & \multicolumn{3}{|c|}{28 Day of Age } & \multicolumn{3}{|c|}{70 Day of Age } & \multicolumn{3}{|c|}{100 Day of Age } & \multirow[b]{2}{*}{ SEM } & \multicolumn{3}{|c|}{$p$-Value } \\
\hline & $\begin{array}{l}C(n \\
=12)\end{array}$ & $\begin{array}{l}E(n \\
=12)\end{array}$ & $\begin{array}{l}\text { EI (n } \\
=12)\end{array}$ & $\begin{array}{l}C(n \\
=12)\end{array}$ & $\begin{array}{l}E(n \\
=12)\end{array}$ & $\begin{array}{l}\text { EI }(n \\
=12)\end{array}$ & $\begin{array}{l}C(n \\
=12)\end{array}$ & $\begin{array}{l}E(n \\
=12)\end{array}$ & $\begin{array}{l}\text { EI }(n \\
=12)\end{array}$ & $\begin{array}{l}C(n \\
=12)\end{array}$ & $\begin{array}{l}E(n \\
=12)\end{array}$ & $\begin{array}{l}\text { EI }(n \\
=12)\end{array}$ & & Group & Time & $\begin{array}{c}\text { Group } \times \\
\text { Time }\end{array}$ \\
\hline $\begin{array}{l}\text { Lysozyme } \\
(\mathrm{mg} / \mathrm{L})\end{array}$ & 0.92 & 0.94 & 1.02 & $0.92^{b}$ & $0.94^{b}$ & $1.05^{\mathrm{a}}$ & $0.86^{\mathrm{B}}$ & $0.98^{\mathrm{B}}$ & $1.12^{\mathrm{A} * *}$ & $0.90^{\mathrm{B}}$ & $1.02^{\mathrm{B} *}$ & $1.16^{\mathrm{A} * *}$ & 0.022 & 0.001 & 0.001 & 0.228 \\
\hline $\begin{array}{l}\text { Ceruloplasmin } \\
(\mathrm{U} / \mathrm{L})\end{array}$ & 51.55 & 51.89 & 52.01 & $50.30^{b}$ & $51.82^{b}$ & $53.09^{a *}$ & $52.26^{\mathrm{B}}$ & $52.02^{\text {B }}$ & $56.81^{\mathrm{A} * *}$ & $51.27^{\text {в }}$ & $52.45^{\text {B }}$ & $56.23^{A * *}$ & 9.00 & 0.004 & 0.002 & 0.890 \\
\hline $\begin{array}{l}\text { Gamma } \\
\text { globulin } \\
(\mathrm{g} / \mathrm{L})\end{array}$ & 26.62 & 26.23 & 26.15 & $23.80^{\mathrm{b}}$ & $26.89^{b}$ & $32.87^{a *}$ & $23.90^{\mathrm{B}}$ & $26.54^{\mathrm{B}}$ & $35.06^{\mathrm{A} * *}$ & $23.55^{\text {B }}$ & $26.38^{B}$ & $35.81^{\mathrm{A} * *}$ & 5.33 & 0.004 & 0.001 & 0.082 \\
\hline $\begin{array}{l}\text { RBA (OD } \\
620 \mathrm{~nm})\end{array}$ & 0.52 & 0.53 & 0.63 & 0.49 & 0.53 & 0.59 & $0.48^{\mathrm{B}}$ & $0.56^{\mathrm{B}}$ & $0.61^{\mathrm{A}}$ & $0.51^{\mathrm{B}}$ & $0.58^{\mathrm{B} *}$ & $0.63^{A}$ & 0.074 & 0.007 & 0.614 & 0.720 \\
\hline $\begin{array}{l}\text { PKA (OD } \\
620 \mathrm{~nm})\end{array}$ & 0.39 & 0.40 & 0.43 & $0.37^{b}$ & $0.45^{b *}$ & $0.48^{\mathrm{a}}$ & $0.37^{\mathrm{b}}$ & $0.44^{b}$ & $0.49^{a *}$ & $0.35^{\mathrm{B}}$ & $0.46^{\mathrm{B} *}$ & $0.52^{A * *}$ & 0.013 & 0.004 & 0.001 & 0.350 \\
\hline $\begin{array}{c}\text { MTT-ConA } \\
\text { (RI) }\end{array}$ & 1.11 & 1.09 & 1.09 & $1.11^{\mathrm{b}}$ & $1.18^{b * *}$ & $1.19^{a * *}$ & 1.13 & $1.17^{* *}$ & $1.19^{* *}$ & $1.13^{b}$ & $1.20^{b * *}$ & $1.21^{\mathrm{a} * *}$ & 0.205 & 0.034 & 0.002 & 0.839 \\
\hline $\begin{array}{l}\text { MTT-LPS } \\
\text { (RI) }\end{array}$ & 1.02 & 1.03 & 1.08 & $0.94^{b}$ & $1.10^{b}$ & $1.16^{a *}$ & $0.90^{\mathrm{B} *}$ & $1.12^{\mathrm{B} *}$ & $1.28^{A * *}$ & 0.98 & 1.08 & 1.15 & 0.055 & 0.012 & 0.049 & 0.080 \\
\hline
\end{tabular}

$\mathrm{a}, \mathrm{b}-p \leq 0.05 ; \mathrm{A}, \mathrm{B}-p \leq 0.01 ;{ }^{*} p \leq 0.05 ;{ }^{* *} p \leq 0.01-$ significant difference relative to day 0 ; SEM-standard error of measurement. RBA — respiratory burst activity, PKA—potential killing activity, MTT-ConA—Proliferative response of T-cells stimulated by mitogen concavalin A, MTT-LPS -Proliferative response of B-cells stimulated by mitogen lipopolysaccharide.

Similar trends were noted in cellular immunity parameters (Table 5). Both non-specific (RBA and PKA of phagocytes) and specific immunity parameters (MTT-ConA and MTTLPS) were higher in experimental lambs. Group EI lambs were characterized by highly significantly higher $(p \leq 0.01)$ values of RBA on days 70 and 100, and PKA on day 100. On days 28 and 70, PKA was significantly higher $(p \leq 0.05)$ in group EI than in the remaining groups. An analysis of the rate of changes in these parameters demonstrated that RBA increased significantly in group $\mathrm{E}$ on day 100 relative to day 0 . Potential killing activity increased significantly on days 28 and 100 in group E lambs, and on days $70(p \leq 0.05)$ and $100(p \leq 0.01)$ in group EI lambs. Specific cellular immunity parameters (MTT-ConA and MTT-LPS) also differed between groups. On days 28 and 100, MTT-ConA was significantly higher in group EI than in the remaining groups. A dynamic analysis revealed a highly significant increase in this parameter on successive days of the experiment relative to day 0 in both groups of lambs. The value of MTT-LPS was significantly higher on day 28 and highly significantly higher on day 70 in group EI than in the remaining groups. Relative to day 0 , MTT-LPS increased significantly on day 70 in groups C and E, and it increased significantly on days $28(p \leq 0.05)$ and $70(p \leq 0.01)$ in group EI.

The Se preparation induced significant changes in the Se status of lambs (Figure 2), regardless of whether it was administered to pregnant ewes (group E) or directly to lambs in the first week of their life (group EI). Serum Se concentration was significantly higher $(p \leq 0.05)$ in group $E$ lambs than in groups $C$ and EI already on day 0 . In comparison with 
the control group, group E lambs were also characterized by higher serum Se concentration on successive sampling dates, but the observed differences were not significant. On days 28,70 , and 100, serum Se levels were significantly highest $(p \leq 0.01)$ in group EI lambs relative to the remaining groups. This parameter was highly significantly higher on all sampling dates relative to day 0 .

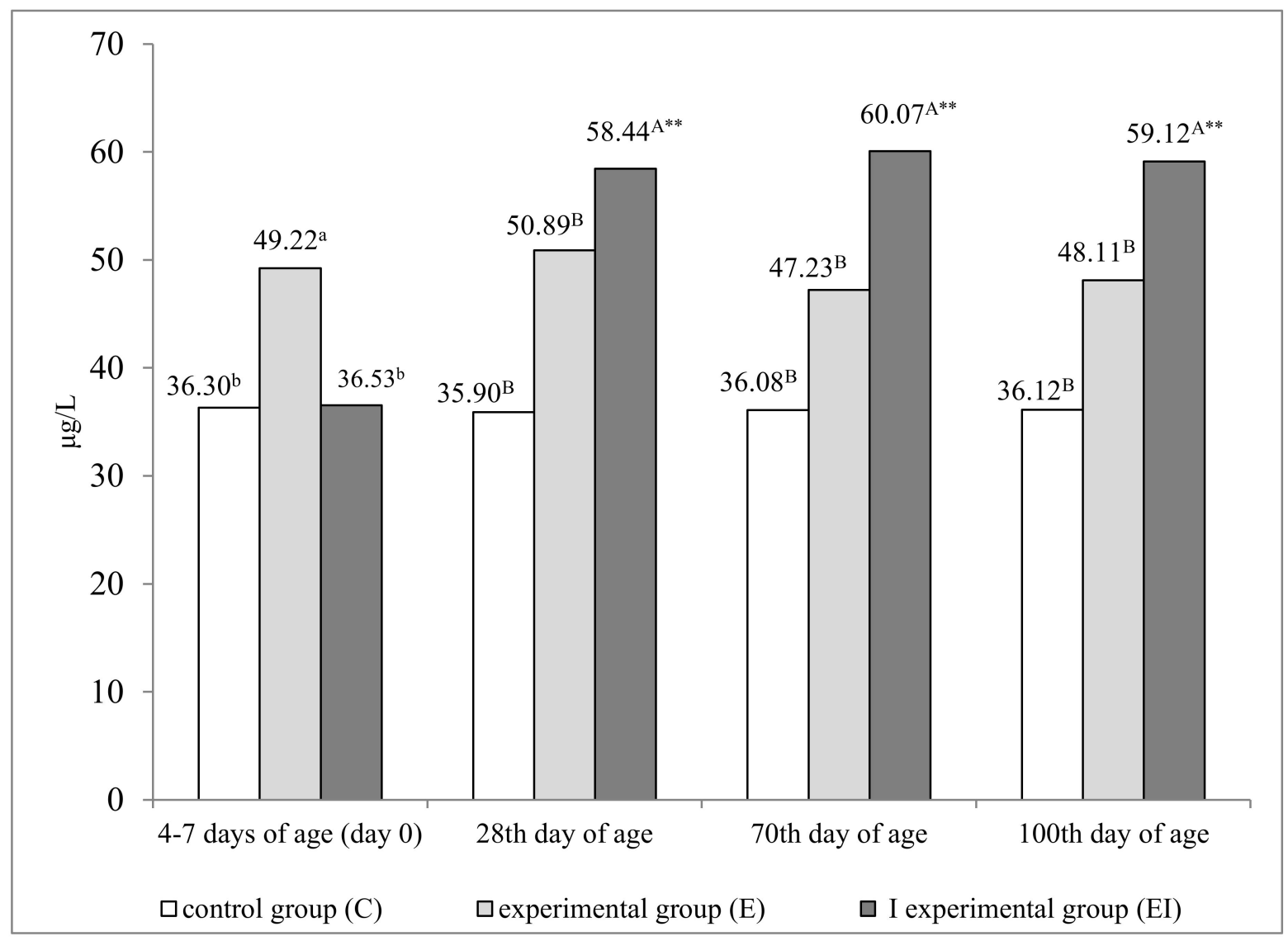

Figure 2. Serum selenium concentration in lambs from control group $\mathrm{C}$, experimental group $\mathrm{E}$, and I experimental group EI $(\mu \mathrm{g} / \mathrm{L}) . \mathrm{a}, \mathrm{b}-p \leq 0.05 ; \mathrm{A}, \mathrm{B}-p \leq 0.01 .{ }^{* *} p \leq 0.01$ - significant difference relative to day 0 .

The growth rate and the results of in vivo measurements performed in lambs are presented in Table 6. At 100 days of age, the average BW of group E and EI lambs was higher by $1.13 \mathrm{~kg}$ and $3.03 \mathrm{~kg}$, respectively, relative to control group lambs. However, significant differences were observed only between group EI lambs and control group animals $(p \leq 0.05)$. The above can be attributed to significantly higher ADG in group EI during the entire rearing period. In group EI, ADG was determined at $269.71 \mathrm{~g}$, and it was $12.79 \%$ higher than in group C $(p \leq 0.05)$. The Se preparation also significantly influenced muscle growth in lambs (Table 6). At 100 days of age, all m.l.d parameters were significantly highest $(p \leq 0.01)$ in group EI. The width and cross-sectional area of m.l.d were significantly higher in group $\mathrm{E}$ than in group C lambs $(p \leq 0.05)$. Fat thickness over the loin eye was similar in all groups. 
Table 6. Body weights, average daily gain, and the results of ultrasonic measurements performed in lambs.

\begin{tabular}{|c|c|c|c|c|c|}
\hline \multirow{2}{*}{ Parameter } & \multicolumn{3}{|c|}{ Group } & \multirow{2}{*}{ SEM } & \multirow{2}{*}{$p$-Value } \\
\hline & $C(n=12)$ & $E(n=12)$ & $\mathrm{EI}(\mathrm{n}=12)$ & & \\
\hline Initial body weight $(\mathrm{kg})-2$ days of age & 5.24 & 5.28 & 5.31 & 0.654 & 0.980 \\
\hline Average body weight $(\mathrm{kg})-4-7$ days of age & 6.08 & 6.16 & 6.26 & 0.698 & 0.916 \\
\hline Final body weight $(\mathrm{kg})$-100 days of age & $28.44^{b}$ & 29.57 & $31.47^{\mathrm{a}}$ & 12.09 & 0.011 \\
\hline Average daily gain-ADG (g) & $239.12^{b}$ & 250.34 & $269.71^{a}$ & 101.10 & 0.073 \\
\hline \multicolumn{6}{|c|}{ m.l.d. at 100 days of age: } \\
\hline height $(\mathrm{cm})$ & $2.18^{\mathrm{B}}$ & 2.26 & $2.38^{\mathrm{A}}$ & 0.048 & 0.007 \\
\hline width $(\mathrm{cm})$ & $5.63^{\mathrm{Bb}}$ & $6.14^{\mathrm{a}}$ & $6.31^{\mathrm{A}}$ & 0.228 & 0.005 \\
\hline cross-sectional area $\left(\mathrm{cm}^{2}\right)$ & $8.63^{\mathrm{Bb}}$ & $10.04^{\mathrm{a}}$ & $10.28^{\mathrm{A}}$ & 1.68 & 0.009 \\
\hline Fat thickness over the loin eye at 100 days of age $(\mathrm{cm})$ & 0.21 & 0.25 & 0.21 & 0.003 & 0.149 \\
\hline
\end{tabular}

$\mathrm{a}, \mathrm{b}-p \leq 0.05 ; \mathrm{A}, \mathrm{B}-p \leq 0.01$. m.1.d.—musculus longissimus dorsi.

\section{Discussion}

\subsection{Selenium Concentration in the Serum and Milk}

This study demonstrated that the long-acting Se preparation increased serum Se concentration in dams, which corroborates the findings of Muñoz et al. [22]. Similar results were reported by other authors who investigated short-acting Se preparations in sheep [23,24]. The administration of Se to pregnant ewes enhanced the Se status of lambs. These observations were confirmed by other researchers who found that Se supplementation during pregnancy prevents Se deficiency in the offspring [25]. However, Barbé et al. [26] observed that the Se content of milk is determined mainly by the availability of Se in cow diets. Selenium was not detected in milk or the serum of cows administered a low dose of the Se supplement $(0.1 \mu \mathrm{g} / \mathrm{g})$, which suggests that a low Se dose is utilized mainly to meet the animals' physiological needs. Serum and milk Se levels increased only in response to supplemental Se doses of 0.2 and $0.3 \mu \mathrm{g} / \mathrm{g}$. In ruminants, Se is transferred more effectively through the placenta than through milk. In general, Se concentration is 3- to 5-fold higher in plasma than in milk [2]. According to Pehrson et al. [27], Se is not effectively transferred to milk; therefore, it does not guarantee healthy Se status in the offspring. In the present study, Se supplementation during pregnancy tended to increase the Se content of milk, and similar observations were made by other authors [28-31].

Literature data are quite divergent in determining the appropriate concentration of Se in the serum or blood content, therefore it is difficult to unequivocally assess the status (deficient, marginal or non-deficient) in ewes and lambs. Grace [32] reports that serum Se concentrations of $<41 \mu \mathrm{g} / \mathrm{L}$ suggest a deficiency of this trace element $41-79 \mu \mathrm{g} / \mathrm{L}$ is a marginal level, and $>79 \mu \mathrm{g} / \mathrm{L}$ is considered the physiological level. However, according to Ghany-Hefnawy [33] the optimal concentration of Se in the blood serum of ewes is higher and should be in between $120-150 \mu \mathrm{g} / \mathrm{L}$.

\subsection{Milk Yield and Composition}

In the current study, Se supplementation had no effect on milk yield or the lactose and protein content of milk, and similar results were reported in cattle by Ferreira and Petzer [34]. According to Juniper et al. [35], Heard et al. [36], and Paschoal [37], organic Se does not affect the percentage content of protein or lactose in milk. Barium selenate injections administered before mating improved milk performance in goats by decreasing SCC and reducing the incidence of clinical mastitis. However, the above supplement had no effect on milk composition [38]. In a study by Saba et al. [39], organic and inorganic Se supplements administered to ewes induced a minor increase in the fat content and the total dry matter content of milk relative to the control group. In the present experiment, Se supplementation also increased the fat content of milk, which indicates that the synthesis and secretion of lipids from the mammary gland were not compromised in dams with lower SCC (group E). Higher SCC in milk intensify lipolytic processes by promoting the 
release of intracellular enzymes, lipases, and proteases. The changes in the milk fat globule membrane induced by lipase (produced by leukocytes) and plasmin (through lipoprotein hydrolysis) increase the content of free fatty acids (FFAs) in milk [40].

\subsection{Blood Parameters}

There is a general scarcity of published studies on the influence of long-acting Se preparations on hematological, biochemical, and immunological parameters in sheep. Only minor changes in the above parameters were noted in the present study. Other researchers reported similar results in calves and correlated these changes with age and physiological development [41].

In this experiment, the significant increase in serum total protein in supplemented lambs probably resulted from an improvement in their Se status. Selenium is responsible for protein biosynthesis, and its deficiency can lead to hypoproteinemia in ruminants [42] The beneficial effects of Se on protein transport and biosynthesis processes were described by El-Shahat and Abdel Monem [43] who reported an increase in serum albumin and total protein levels in lambs whose dams received Se and vitamin E supplements during pregnancy.

In the current study, Se supplementation did not affect glucose levels in lambs, and similar observations were made by Abdel-Raheem et al. [44]. Triglyceride concentrations increased in control group lambs in the last stage of the experiment. Similar changes were reported by Sobiech [45] in a study of goat kids with nutritional muscular dystrophy (NMD) caused by selenium deficiency. In the present study, the significant increase in triacylglycerol levels in control group lambs could suggest that lipolysis was intensified due to Se deficiency.

Cholesterol concentration was somewhat higher in the experimental lambs, which can probably be attributed to Se supplementation. Such an effect was also noted by AbdelRaheem et al. [44] in ewes supplemented with Se. Lower serum cholesterol in control group lambs suggests that Se deficiency could impair liver function and cholesterol synthesis.

The activities of AST and GGT were similar in all groups during the experiment, and remained within the reference ranges for lambs [46]. It should be noted that AST and GGT have the highest affinity for liver tissue; therefore, the lack of significant differences in their activities between groups points to the absence of pathological changes in the liver. The activity of LDH also remained fairly stable during the experiment. This parameter should be analyzed in young ruminants which are prone to Se deficiency and, consequently, NMD [46]. Based on the results of this study, pathological changes in muscle tissues were ruled out in all animals.

Minor fluctuations in ALP activity were observed during the study, but the noted differences were not statistically significant. The observed variations were associated with physiological maturation as well as ossification processes where ALP plays an important role [47].

The results of the present study indicate that the Se preparation enhanced defense mechanisms in lambs by increasing lysozyme activity, ceruloplasmin activity, gamma globulin levels, RBA and PKA of phagocytes, and the proliferation of mitogen-stimulated lymphocytes (MTT-ConA and MTT-LPS). As a result, the analyzed preparation enhanced both humoral and cellular immunity in lambs. The beneficial effects of Se on the immune system have also been described by other authors $[23,48]$. Selenium participates in immune processes, and Se compounds enhance humoral immunity and increase the concentration of immunoglobulin M [49]. Dietary Se supplements increase antibody production, enhance the phagocytic activity of neutrophils and macrophages, and increase $\mathrm{T}$ cell counts after mitogen stimulation [50]. Rock et al. [48] demonstrated that prenatal Se supplementation in ewes improved IgG absorption from the small intestine in lambs; therefore, the offspring of control dams were characterized by lower serum IgG levels that the offspring of experimental dams administered Se supplements during pregnancy. The same authors also found that prenatal Se supplementation increased serum IgG levels in calves. These findings 
indicate that Se supplements can influence IgM synthesis in dams and IgG absorption in newborns.

\subsection{Lamb's Growth Rate and Indicators of Musculature and Fatness}

The analyzed Se supplement stimulated the growth rate and muscle development in lambs without affecting carcass fatness. These effects were more pronounced in lambs that were directly injected with barium selenate. These lambs were characterized by larger cross-sectional area of m.l.d. and higher meatiness [21]. It should be stressed that the above changes were not accompanied by an increase in fatness, as demonstrated by similar fat thickness over the loin eye. The growth rate was somewhat higher in the offspring of dams receiving the Se preparation, which could be attributed to the influence of Se on the chemical composition of milk that was more abundant in fat and, consequently, dry matter. The results of studies investigating the growth-promoting effects of Se supplements in lambs are inconclusive. These discrepancies could be attributed to differences in the administered forms of supplemental Se, different dietary levels of Se, and interactions with other chemical compounds. According to many authors, Se combined with vitamin $\mathrm{E}$ improved ADG and feed conversion efficiency $[51,52]$ in lambs, whereas Se administered with yeast improved growth performance in lambs [53] and growing male goats [54]. In a study by Mohri et al. [55], Se and vitamin E supplements did not affect the final BW or ADG of lambs. Alimohamady et al. [56], Sushma et al. [57], and Vignola et al. [58] found that Se supplementation did not influence growth performance in lambs. Selenium also did not considerably affect the growth rate of buffalos [59], or ADG, feed intake, and feed conversion in goats [60]. In contrast, Kumar et al. [61] and Ibrahim and Mohamed [62] reported higher ADG in sheep whose diets were supplemented with various sources of Se. Kumar et al. [63] observed a higher growth rate in lambs receiving Se supplements (0.15 or $0.3 \mathrm{ppm}$ ), but significant differences were not reported between groups administered different doses of Se. Dietary Se supplementation significantly increased BW gain in goat kids: The BW determined in experimental group kids at 5 months of age was achieved by control group kids at 7.5 months of age [64].

The effects of Se preparations administered to ewes on the growth rate of lambs were analyzed by many authors. Gabryszuk and Klewiec [65] found that Se injections administered to dams before mating enhanced the growth performance of their offspring. The above results are consistent with the findings of Muñoz et al. [22] who observed that the offspring of dams administered barium selenate were characterized by similar birth weight, but significantly higher ADG during rearing than control group lambs. Zarbalizadeh-Saed et al. [66] and Abdel-Raheem et al. [44] also reported a significantly higher growth rate of the offspring of dams whose diets were supplemented with Se. Similar results were noted by El-Shahat and Abdel Monem [44] and Soliman et al. [67] who injected dams with Se and vitamin E, and Saba et al. [39] who supplemented ewe diets with Se yeast. The mechanism responsible for the growth-promoting effects of Se and vitamin $\mathrm{E}$ has not been fully elucidated to date. Pisek et al. [68] suggested that Se supplements could promote growth by enhancing the activity of thyroid hormones. The growth-promoting effects of Se supplements could also be attributed to the antioxidant properties of glutathione peroxidase (GPx), which is a Se-containing enzyme [44].

\section{Conclusions}

The results of the present study support the formulation of the following conclusions:

1. Barium selenate significantly improved the Se status of lambs, regardless of whether it was administered to pregnant ewes (E group) or directly to lambs in the first week of their life (EI group).

2. The milk of ewes receiving the Se supplement was characterized by significantly higher fat content and, consequently, higher dry matter concentration.

3. The analyzed Se preparation induced significant changes in immunological parameters, thus enhancing defense mechanisms in lambs. 
4. The preparation in the form of barium selenate (VI) administered to lambs from the EI group had a more stimulating effect on their humoral and cellular immune response than in the lambs from the E group, where the preparation was administered to their mothers.

The results of this study indicate that the long-acting Se preparation delivers benefits to sheep by enhancing their immunity and, therefore, improving productivity.

Author Contributions: Conceptualization, S.M. and P.S.; methodology, S.M., K.Z. and J.B.-G.; investigation, K.Ż. and R.W.; data curation P.S.; writing-original draft, J.B.-G.; writing-review and editing, J.M. and K.Z.; All authors have read and agreed to the published version of the manuscript.

Funding: Project financially supported by Minister of Science and Higher Education in the range of the program entitled "Regional Initiative of Excellence" for the years 2019-2022, Project No. 010/RID/2018/19, amount of funding 12.000.000 PLN.

Institutional Review Board Statement: Not applicable.

Institutional Review Board Statement: The study was conducted according to the guidelines of the Declaration of Helsinki, and approved by the Local Ethics Committee for Animal Experimentation of the University of Warmia and Mazury in Olsztyn, Poland (protocol code 68/2014 and 10.12.2014 date of approval).

Informed Consent Statement: Not applicable.

Data Availability Statement: Not applicable.

Conflicts of Interest: We certify that there is no conflict of interest with any financial organization regarding the material discussed in the manuscript.

\section{References}

1. Stec, A.; Mochol, J.; Kurek, Ł.; Wałkuska, G.; Chałabis-Mazurek, A. The influence of different factors on selenium levels in dairy cow herds in the central-eastern region of Poland. Pol. J. Vet. Sci. 2005, 8, 225-229. [PubMed]

2. Mehdi, Y.; Dufrasne, I. Selenium in cattle: A review. Molecules 2016, 21, 545. [CrossRef] [PubMed]

3. Čobanová-Boldižárová, K.; Grešáková, L.; Faix, Š.; Petrovič, V.; Leng, L. Selenium in Sheep Nutrition. In Current Advances in Selenium Research and Applications; Surai, P., Taylor-Pickard, J.A., Eds.; Wageningen Academic Publishers: Wageningen, The Netherlands, 2008; pp. 209-220.

4. Koenig, K.M.; Rode, L.M.; Cohen, R.D.; Buckley, W.T. Effects of diet and chemical form of selenium on selenium metabolism in sheep. J. Anim. Sci. 1997, 75, 817-827. [CrossRef]

5. Lenartova, V.; Holovska, K.; Javorsky, P. The influence on the antioxidant enzyme activity of rumen bacteria Streptococcus bovis and Selenomonas ruminantium. FEMS Microbiol. Ecol. 1998, 27, 319-325. [CrossRef]

6. Deore, M.; Dumka, V.; Sharma, S.; Srivastava, A. Selenium toxicokinetics after oral and intravenous administration in buffalo calves. Environ. Toxicol. Pharmacol. 2007, 24, 55-59. [CrossRef] [PubMed]

7. Mynhardt, H.; Van Ryssen, J.B.J.; Coertze, R.J. The effect of heat processing of soybean seed on the metabolism of its selenium in lambs. Animal Feed Sci. Technol. 2006, 128, 122-134. [CrossRef]

8. Annett, R.W.; Carson, A.F.; Fearon, A.M.; Kilpatrick, D.J. Effects of supplementation with fish oil and barium selenate on performance, carcass characteristics and muscle fatty acid composition of late season lamb finished on grass-based or concentratebased diets. Animals 2011, 5, 1923-1937. [CrossRef]

9. Ceballos, A.; Sánchez, J.; Stryhn, H.; Montgomery, J.B.; Barkema, H.W.; Wichtel, J.J. Meta-analysis of the effect of oral selenium supplementation on milk selenium concentration in cattle. J. Dairy Sci. 2009, 92, 324-342. [CrossRef]

10. Barham, D.; Trinder, P. An improved colour reagent for the determination of blood glucose by the oxidase system. Analyst 1972, 97, 142-145. [CrossRef]

11. Tietz, N.W. Clinical Guide to Laboratory Tests, 3rd ed.; WB Saunders: Philadelphia, PA, USA, 1995; p. 518.

12. Lie, R.F.; Schurtz, J.M.; Kenneth, J.P.; Gochonan, N. Cholesterol oxidase-based determination by continuous-flow analysis of total and free cholesterol in serum. Clin. Chem. 1976, 22, 1627-1630. [CrossRef]

13. McGowan, M.W.; Artiss, J.D.; Stranbergh, D.R.; Zak, B. A peroxidase-coupled method for colorimetric determination of serum triglycerides. Clin. Chem. 1983, 29, 538-542. [CrossRef]

14. Huang, X.; Chai, J.; Im, H.; Yarimaga, O.; Yoon, E.; Kim, H. Aspartate aminotransferase (AST, GOT) and alanine aminotransferase (ALT, GPT) detection techniques. Sensors 2006, 6, 756-782. [CrossRef]

15. Burtis, C.A.; Ashwood, E.R. Tietz Textbook of Clinical Chemistry, 2nd ed.; WB Saunders: Philadelphia, PA, USA, 1994; pp. 816-818.

16. Tietz, N.W. Clinical Guide to Laboratory Tests, 3rd ed.; WB Saunders: Philadelphia, PA, USA, 1995; p. 286. 
17. Burtis, C.A.; Ashwood, E.R. Tietz Textbook of Clinical Chemistry and Molecular Diagnostics, 4th ed.; WB Saunders: St. Louis, MO, USA, 2006; p. 2290.

18. Siwicki, A.K.; Anderson, D.P. Immunostimulation in Fish: Measuring the Effects of Stimulants by Serological and Immunological Methods; U.S. Fish Wild, IFI: Olsztyn, Poland, 1993; pp. 1-17.

19. Siwicki, A.K.; Studnicka, M. Ceruloplasmin activity in carp (Cyprinus carpio). Bamidgeh 1986, 38, $126-129$.

20. Zabek, K.; Milewski, S.; Wójcik, R.; Siwicki, A.K. The effects of supplementing diets fed to pregnant and lactating ewes with saccharomyces cerevisiae dried yeast. Turk. J. Vet Anim. Sci. 2014, 38, 200-206. [CrossRef]

21. Junkuszew, A.; Ringdorfer, F. Computer tomography and ultrasound measurement as methods for the prediction of the body composition of lambs. Small Rumin. Res. 2005, 56, 121-125. [CrossRef]

22. Muñoz, C.; Carson, A.F.; McCoy, M.A.; Dawson, L.E.R.; Irwin, D.; Gordon, A.W.; Kilpatrick, D.J. Effect of supplementation with barium selenate on the fertility, prolificacy and lambing performance of hill sheep. Vet. Rec. 2009, 164, 265-271. [CrossRef] [PubMed]

23. Čobanová, K.; Faix, Š.; Plachá, I.; Mihaliková, K.; Váradyová, Z.; Kišidayová, S.; Grešáková, L'. Effects of different dietary selenium sources on antioxidant status and blood phagocytic activity in sheep. Biol. Trace. Elem. Res. 2017, 175, 339-346. [CrossRef]

24. Novoselec, J.; Šperanda, M.; Klir, Ž.; Mioč, B.; Steiner, Z.; Antunović, Z. Blood biochemical indicators and concentration of thyroid hormones in heavily pregnant and lactating ewes depending on selenium supplementation. Acta Vet. Brno. 2017, 86, 353-363. [CrossRef]

25. Ramirez, B.E.; Hernandez, C.E.; Hernandez, L.M.; Tortora-Perez, J.L. Effect of parenteral supplement with sodium selenite on lamb mortality and hematic values of selenium. Agrociencia 2004, 38, 43-51.

26. Barbé, F.; Chevaux, E.; Castex, M.; Elcoso, G.; Bach, A. Comparison of selenium bioavailability in milk and serum in dairy cows fed different sources of organic selenium. Anim. Prod. Sci. 2020, 60, 269-276. [CrossRef]

27. Pehrson, B.; Ortman, K.; Madjid, N.; Trafikowska, U. The influence of dietary selenium as selenium yeast or sodium selenite on the concentration of selenium in the milk of suckler cows and on the selenium status of their calves. J. Anim. Sci. 1999, 77, 3371-3376. [CrossRef]

28. Ceballos, A.; Kruze, J.; Barkema, H.W.; Dohoo, I.R.; Sanchez, J.; Uribe, D.; Wichtel, J.J.; Wittwer, F. Barium selenate supplementation and its effect on intramammary infection in pasture-based dairy cows. J. Dairy Sci. 2010, 93, 1468-1477. [CrossRef] [PubMed]

29. Horkỳ, P. Effect of selenium on its content in milk and performance of dairy cows in ecological farming. Potravinarstvo 2015, 9 , 324-329. [CrossRef]

30. Ran, L.; Wu, X.; Shen, X.; Zhang, K.; Ren, F.; Huang, K. Effects of selenium form on blood and milk selenium concentrations, milk component and milk fatty acid composition in dairy cows. J. Sci. Food Agric. 2010, 90, 2214-2219. [CrossRef]

31. Salman, S.; Dinse, D.; Khol-Parisini, A.; Schafft, H.; Lahrssen-Wiederholt, M.; Schreiner, M.; Scharek-Tedin, L.; Zentek, J. Colostrum and milk selenium, antioxidative capacity and immune status of dairy cows fed sodium selenite or selenium yeast. Arch. Anim. Nutr. 2013, 67, 48-61. [CrossRef]

32. Grace, N.D. Use of biochemical criteria to diagnose trace element deficiencies in sheep and cattle. In Proceedings of the 9th International Conference on Animal Production, Berlin, Germany, 11-14 September 1997.

33. Ghany-Hefnawy, A.E.; López-Arellano, A.E.; Revilla-Vázquez, R.; Ramírez-Bribiesca, A.; Tórtora-Pérez, J.L. Interrelationship between fetal and maternal selenium concentrations in small ruminants. Small Rumin. Res. 2007, 73, 174-180. [CrossRef]

34. Ferreira, G.M.; Petzer, I.M. Injectable organic and inorganic selenium in dairy cows-Effects on milk, blood and somatic cell count levels. Onderstepoort J. Vet. Res. 2019, 86, 1-8. [CrossRef]

35. Juniper, D.T.; Phipps, R.H.; Jones, A.K.; Bertin, G. Selenium supplementation of lactating dairy cows: Effect on selenium concentration in blood, milk, urine, and feces. J. Dairy Sci. 2006, 89, 3544-3551. [CrossRef]

36. Heard, J.W.; Stockdale, C.R.; Walker, G.P.; Leddin, C.M.; Dunshea, F.R.; Mclnstosh, G.H.; Shields, P.M.; McKenna, A.; Young, G.P.; Doyle, P.T. Increasing selenium concentration in milk: Effects of amount of selenium from yeast and cereal grain supplements. J. Dairy Sci. 2007, 90, 4117-4127. [CrossRef]

37. Paschoal, J.J.; Zanetti, M.A.; Del Claro, G.R.; Melo, M.P.D.; Pugine, S.P.; Cunha, J.A. Fatty acid profile and oxidative stability of milk from Holstein cows fed with extruded soybean and organic selenium. Pesqui. Agropecu. Bras. 2007, 42, 1793-1799. [CrossRef]

38. Sánchez, J.; Montes, P.; Jimenez, A.; Andres, S. Prevention of clinical mastitis with barium selenate in dairy goats from a selenium-deficient area. J. Dairy Sci. 2007, 90, 2350-2354. [CrossRef] [PubMed]

39. Saba, F.E.; Saleh, A.A.K.; Al Moafy, A.A. Effect of supplementation with different types of selenium on lactation performance and some blood parameters of Farafra and Saidi ewes and performance of their lambs. Egypt. J. Sheep Goats Sci. 2019, 14, 19-30. [CrossRef]

40. Alhussien, M.N.; Dang, A.K. Milk somatic cells, factors influencing their release, future prospects, and practical utility in dairy animals: An overview. Vet. World 2018, 11, 562. [CrossRef]

41. Moosavian, H.R.; Mohri, M.; Seifi, H.A. Effect of parenteral over-supplementation of vitamin A and iron hematology, iron biochemistry, weight gain, and health of neonatal dairy calves. Food Chem. Toxicol. 2010, 48, 1316-1320. [CrossRef] [PubMed]

42. Gerloff, B.J. Effect of selenium supplementation on dairy cattle. J. Anim. Sci. 1992, 70, 3934-3940. [CrossRef]

43. El-Shahat, K.H.; Abdel Monem, U.M. Effects of dietary supplementation with vitamin E and/or selenium on metabolic and reproductive performance of Egyptian Baladi ewes under subtropical conditions. World App. Sci. J. 2011, 12, 1492-1499. 
44. Abdel-Raheem, S.; Mahmoud, G.; Senosy, W.; El-Sherry, T. Influence of vitamin E and selenium supplementation on the performance, reproductive indices and metabolic status of ossimi ewes. Slov. Vet. Res. 2019, 56 (Suppl. 22), 353-363. [CrossRef]

45. Sobiech, P. Obraz Hematologiczny, Biochemiczny i Histopatologiczny Pokarmowej Dystrofii Mięśni Koźlat (Hematological, Biochemical and Histopathological Picture of Nutritional Muscular Dystrophy [NMD] in Goat Kids); Monography/dissertation; UWM: Olsztyn, Poland, 2009.

46. Sobiech, P.; Kuleta, Z. Usefulness of some biochemical indicators in detection of early stages of nutritional muscular dystrophy in lambs. Small Rumin. Res. 2002, 45, 209-215. [CrossRef]

47. Sousa, C.P.; De Azevedo, J.T.; Silva, A.M.; Viegas, C.A.; Rei, R.L.; Gomes, M.E.; Dias, I.R. Serum total and bone alkaline phosphatase levels and their correlation with serum minerals over the lifespan of sheep. Acta Vet. Hung. 2014, 62, 1-10. [CrossRef]

48. Rock, M.J.; Kincaid, R.I.; Carstens, G.E. Effects of prenatal source and level of dietary selenium on passive immunity and thermometabolism of newborn lambs. Small Rumin. Res. 2000, 40, 129-138. [CrossRef]

49. Maggini, S.; Wintergerst, E.S.; Beveridge, S.; Horning, D.H. Selected vitamins and trace elements support immune function by strengthening epithelial barriers and cellular and humoral immune responses. Br. J. Nut. 2007, 98, 29-35. [CrossRef] [PubMed]

50. Hoffman, P.R. Mechanisms by which selenium influences immune responses. Arch. Immunol. Ther. Exp. 2007, 55, 289-297. [CrossRef] [PubMed]

51. Chauhan, S.S.; Ponnampalam, E.N.; Celi, P.; Hopkins, D.L.; Leury, B.J.; Dunshea, F.R. High dietary vitamin E and selenium improves feed intake and weight gain of finisher lambs and maintains redox homeostasis under hot conditions. Small Rumin. Res. 2016, 137, 17-23. [CrossRef]

52. Soliman, E.B. Changes in productive performance, hemato-biochemical indices, immune and antioxidant status of growing Ossimi lambs subjected to vitamins A and E administration. Egypt. J. Sheep Goats Sci. 2015, 10, 1-14. [CrossRef]

53. Huang, Y.B.; Sun, Y.W.; Zhou, J.Q.; GUO, L. Effects of organic selenium sources on lamb's growth performance and its antioxidative activities. Anim. Husb. Feed Sci. 2009, 9, 13.

54. Shi, L.; Xun, W.; Yue, W.; Zhang, C.; Ren, Y.; Shi, L.; Lei, F. Effect of sodium selenite, Se-yeast and nano-elemental selenium on growth performance, Se concentration and antioxidant status in growing male goats. Small Rumin. Res. 2011, 96, 49-52. [CrossRef]

55. Mohri, M.; Ehsani, A.; Norouzian, M.A.; Bami, M.H.; Seifi, H.A. Parenteral selenium and vitamin e supplementation to lambs: Hematology, serum biochemistry, performance, and relationship with other trace elements. Biol. Trace Elem. Res. 2011, 139, 308-316. [CrossRef]

56. Alimohamady, R.; Aliarabi, H.; Bahari, A.; Dezfoulian, A.H. Influence of different amounts and sources of selenium supplementation on performance, some blood parameters, and nutrient digestibility in lambs. Biol. Trace Elem. Res. 2013, 154, 45-54. [CrossRef]

57. Sushma, K.; Reddy, Y.R.; Kumari, N.N.; Reddy, P.B.; Raghunandan, T.; Sridhar, K. Effect of selenium supplementation on performance, cost economics, and biochemical profile of Nellore ram lambs. Vet. World 2015, 8, 1150-1155. [CrossRef]

58. Vignola, G.; Lambertini, L.; Mazzone, G.; Giammarco, M.; Tassinari, M.; Martelli, G.; Bertin, G. Effects of selenium source and level of supplementation on the performance and meat quality of lambs. Meat Sci. 2009, 81, 678-685. [CrossRef]

59. Mudgal, V.; Garg, A.K.; Dass, R.S. Effect of dietary selenium and copper supplementation on growth and nutrient utilization in buffalo (Bubalus bubalis) calves. Anim. Nutr. Feed Technol. 2007, 7, 79-88.

60. Aghwan, Z.A.; Sazili, A.Q.; Kadhim, K.K.; Alimon, A.R.; Goh, Y.M.; Adeyemi, K.D. Effects of dietary supplementation of selenium and iodine on growth performance, carcass characteristics and histology of thyroid gland in goats. Anim. Sci. J. 2016, 87, 690-696. [CrossRef]

61. Kumar, N.; Garg, A.K.; Dass, R.S.; Chaturvedi, V.K.; Mudgal, V.; Varshney, V.P. Selenium supplementation influences growth performance, antioxidant status and immune response in lambs. Anim. Feed Sci. Technol. 2009, 153, 77-87. [CrossRef]

62. Ibrahim, E.M.; Mohamed, M.Y. Effect of Different Dietary Selenium Sources Supplementation on Nutrient Digestibility, Productive Performance and Some Serum Biochemical Indices in Sheep. Egypt. J. Nutr. Feeds 2018, 21, 53-64. [CrossRef]

63. Kumar, N.; Garg, A.K.; Mudgal, V.; Dass, R.S.; Chaturvedi, V.K.; Varshney, V.P. Effect of different levels of selenium supplementation on growth rate, nutrient utilization, blood metabolic profile, and immune response in lambs. Biol. Trace Elem. Res. 2008, 126, 44-56. [CrossRef]

64. Mojapelo, M.M.; Lehloenya, K.C. Effect of selenium supplementation on attainment of puberty in Saanen male goat kids. Theriogenology 2019, 138, 9-15. [CrossRef] [PubMed]

65. Gabryszuk, M.; Klewiec, J. Effect of injecting 2- and 3-year-old ewes with selenium and selenium-vitamin E on reproduction and rearing of lambs. Small Rumin. Res. 2002, 43, 127-132. [CrossRef]

66. Zarbalizadeh-Saed, A.; Seifdavati, J.; Abdi-Benemar, H.; Salem, A.Z.; Barbabosa-Pliego, A.; Camacho-Diaz, L.M.; Fadayifar, A.; Seyed-Sharifi, R. Effect of Slow-Release Pellets of Selenium and Iodine on Performance and Some Blood Metabolites of Pregnant Moghani Ewes and Their Lambs. Biol. Trace Elem. Res. 2019, 1-11. [CrossRef]

67. Soliman, E.B.; AKI, A.E.M.; Kassab, A.Y. Combined effect of vitamin E and selenium on some productive and physiological characteristics of ewes and their lambs during suckling period. Egypt. J. Sheep Goat Sci. 2012, 7, 31-42. [CrossRef]

68. Pisek, L.; Travnicek, J.; Salat, J.; Kroupova, V.; Soch, M. Changes in white blood cells in sheep blood during selenium supplementation. Vet. Med. 2008, 53, 255-259. [CrossRef] 